Organic Chemical Laboratory,

Catholic University of Nijmegen, Netherlands1), and

Research Laboratories of the Pharmaceuticals Division of

CIBA-GEIGY Limited, Basle, Switzerland2)

\title{
BIOLOGICAL ACTIVITY OF CORTICOTROPHIN PEPTIDES WITH HOMO-ARGININE, LYSINE OR ORNITHINE SUBSTITUTED FOR ARGININE IN POSITION 8
}

By

\author{
Godefridus I. Tesser, ${ }^{1}$ René Maier, ${ }^{2}$ Lotte Schenkel-Hulliger, 2 \\ Pierre L. Barthe, ${ }^{2}$ Bruno Kamber ${ }^{2}$ and Werner Rittel ${ }^{2}$
}

\begin{abstract}
A B S T R A C T
The steroidogenic and lipolytic activities of corticotrophin-(1-24)-tetracosapeptide and [Lys 17,18] corticotrophin-(1-18)-octadecapeptide amide were compared with those of the corresponding analogues variously substituted in position 8 with homo-arginine, ornithine or lysine. Peptides substituted with homo-arginine showed a surprisingly high degree of biological activity; in all the tests performed, the loss of activity due to the substitution did not exceed a factor of 3 to 10 , while peptides substituted with ornithine or lysine in position 8 only showed residual biological activity or none at all, depending on the test system used. The results reported demonstrated that the presence of a guanidino group (arginine or homo-arginine side chain) in position 8 of the ACTH peptide is essential for the preservation of a high level of biological activity; the length of the aliphatic chain carrying the guanidino group is of minor importance.
\end{abstract}



In previous communications (Tesser \& Schwyzer 1966; Tesser \& Rittel 1969), the effect of the substitution of ornithine (cf. formulae, Table 1) for the arginine residue in positions 8,17 and 18 of corticotrophin-(1-24)-tetracosapeptide (I) ${ }^{1}$ was described.

It was shown that as far as the biological activity of the peptide is concerned the presence of a guanidino group in position 8 is more important than the presence of such a group in positions 17 or 18 . The need for arginine ${ }^{8}$ had already been demonstrated earlier by Chung \& $L i$ (1967), who found that the biological activity of corticotrophin (1-17) heptadecapeptide amide substituted with lysine ${ }^{8}$ was remarkably weak as compared with that of the peptide containing arginine ${ }^{8}$. In addition, according to Geiger (1971) and Schwyzer et al. (1971) the active site of corticotrophin is located between positions 5 and 10; arginine $^{8}$ is thus one of the amino acids composing the active centre.

In the present studies, the effect of structural alterations in position 8 on steroidogenic and lipolytic activity has been further investigated.

Peptides substituted in position 8 with homo-arginine, ornithine or lysine were compared with the unmodified peptide containing arginine.

\section{MATERIAL AND METHODS}

Peptides. - The synthesis of the analogues II and VI will be described elsewhere (Tesser et al., in prep.). Peptide I was prepared according to Kappeler \& Schwyzer (1961); III was synthesized by Tesser \& Rittel (1969). Peptides IV and V were prepared by a route analogous to that used in the synthesis of I (Kamber et al., unpublished results). The structures of the tested peptides are shown in Table 1.

Steroidogenesis. - In vitro, adrenal slices were incubated for $2 \mathrm{~h}$ according to the method described by Saffran \& Schally (1955). The corticosterone content of the incubation medium was measured by acid fluorescence (Guillemin et al. 1959).

In vivo, the peptides were injected once intravenously into male rats hypophysectomized $24 \mathrm{~h}$ previously. The concentration of corticosterone in the plasma was determined as described by Desaulles \& Rittel (1968).

Lipolysis. - In the in vitro experiments, epididymal fat pads from rats were incubated essentially as described by Jungas \& Ball (1963); $4 \%$ bovine albumin was added. After two hours' incubation the unesterified fatty acids (FFA) released into the incubation medium were measured by titration (Dole 1956), and the glycerol content estimated as described by Wieland (1957).

Lipolytic activity in vivo was estimated on the basis of the concentration of unesterified fatty acids determined colorimetrically in the plasma (Duncombe 1963), 30 min after the intravenous administration of the peptide.

1) Nomenclature according to the recommendations of the IUPAC-IUB Commission of Biochemical Nomenclature (1972).

Other abbreviations used: Har = homo-arginine, FFA = unesterified fatty acids, i. e. lysine $e^{8}=$ lysine in position 8 of the amino acid sequence. 
Table 1.

Formulae of the corticotrophin peptides tested.

\begin{tabular}{|c|c|c|c|c|c|c|c|c|c|c|c|c|c|c|c|c|c|c|c|c|c|c|c|}
\hline 1 & 2 & 3 & 4 & 5 & 6 & 7 & 8 & 9 & 10 & 11 & 12 & 13 & 14 & 15 & 16 & 17 & 18 & 19 & 20 & 21 & 22 & 23 & 24 \\
\hline I: H-Ser & Tyr & Ser & Met & Glu & His & Phe & Arg & Trp & Gly & Lys & Pro & Val & Gly & Lys & Lys & Arg & Arg & Pro & Val & Lys & Val & Tyr & Pro-OH \\
\hline II: H-Ser & & & & & & & Har & & & & & & & & & Arg & Arg & & & & & & Pro-OH \\
\hline III: H-Ser & & & & & & & Orn & & & & & & & & & $\operatorname{Arg}$ & Arg & & & & & & Pro-OH \\
\hline IV: H-Ser & & & & & & & Lys & & & & & & & & & Arg & Arg & & & & & & Pro-OH \\
\hline V: H-Ser & & & & & & & Arg & & & & & & & & & Lys & Lys & $\mathrm{NH}_{2}$ & & & & & \\
\hline VI: H-Ser & & & & & & & Har & & & & & & & & & Lys & Lys & $\mathrm{NH}_{2}$ & & & & & \\
\hline \multicolumn{24}{|c|}{ I: corticotrophin-(1-24)-tetracosapeptide } \\
\hline \multicolumn{24}{|c|}{ II: $\left[\mathrm{Har}^{8}\right]$ corticotrophin-(1-24)-tetracosapeptide } \\
\hline \multicolumn{24}{|c|}{ III: $\left[\mathrm{Orn}^{8}\right]$ corticotrophin-(1-24)-tetracosapeptide } \\
\hline \multicolumn{24}{|c|}{ IV: $\left[\right.$ Lys $\left.^{8}\right]$ corticotrophin-(I-24)-tetracosapeptide } \\
\hline \multicolumn{24}{|c|}{ V: [Lys $\left.{ }^{17,18}\right]$ corticotrophin-(1-18)-octadecapeptide amide } \\
\hline VI: [Har & Lys 17 & ,18] cor & ticotr & phin- & (1-18) & )-octad & decape & eptide & amide & & & & & & & & & & & & & & \\
\hline
\end{tabular}


Animals. - The experiments were performed on male albino rats of the SpragueDawley strain (Ivanovas, Kisslegg, Germany) which had been kept on a standard laboratory diet and under controlled lighting conditions. The in vitro steroidogenesis assays were carried out with adrenals excised from animals weighing 180-200 g. In the in vitro lipolytic assays, epididymal fat from rats weighing $140-160 \mathrm{~g}$ was used. Rats weighing 180-200 $\mathrm{g}$ were selected for the in vivo experiments.

Statistical analysis. - Dose-response curves were constructed from the mean data derived from 6 to 10 experiments. Regression lines within the linear part of the dose-response curves were calculated by the Hewlett-Packard programme Stat-Pac V-6. The relative steroidogenic potencies of the peptides in vitro were determined in 4-point assays by means of parallel regression analysis (Finney 1964).

\section{RES UL T S}

\section{Steroidogenesis in vitro (Fig. 1, Table 2)}

The dose-response regression lines of the two standard preparations, I and V, do not differ significantly, though the latter peptide is slightly more active

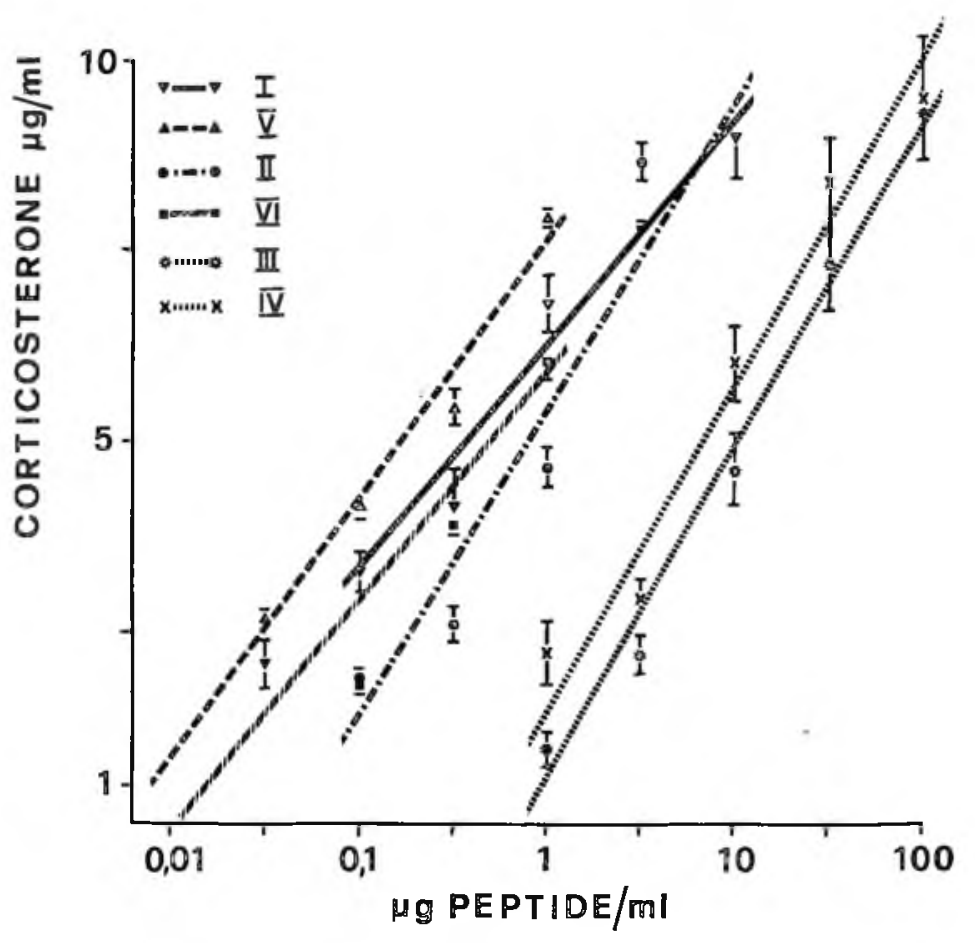

Fig. 1.

In vitro steroidogenesis: Dose-response regression lines of corticosterone released from rat adrenal slices incubated for $2 \mathrm{~h}$ at $37^{\circ} \mathrm{C}$. Each point constitutes the mean of 6 to 10 incubations \pm SEM. 
Table 2.

In vitro steroidogenesis: relative potencies determined in four point assays. (adrenal slices of rats incubated for 2 hours).

\begin{tabular}{c|c|c|c}
\hline $\begin{array}{c}\text { Standard } \\
\text { compound }\end{array}$ & $\begin{array}{c}\text { Test } \\
\text { compound }\end{array}$ & Potency & $\begin{array}{c}\text { Confidence } \\
\text { limits } 95 \%\end{array}$ \\
\hline I & II & 0.25 & $0.28-0.28$ \\
I & III & $0.036^{*}$ & $0.029-0.046$ \\
I & IV & $0.076^{*}$ & $0.061-0.094$ \\
& & $0.046^{*}$ & $0.024-0.082$ \\
V & VI & 0.25 & $0.19-0.33$ \\
& & 0.24 & $0.20-0.29$ \\
\hline
\end{tabular}

* Owing to significant differences in the slopes of the dose-response curves a valid comparison cannot be made.

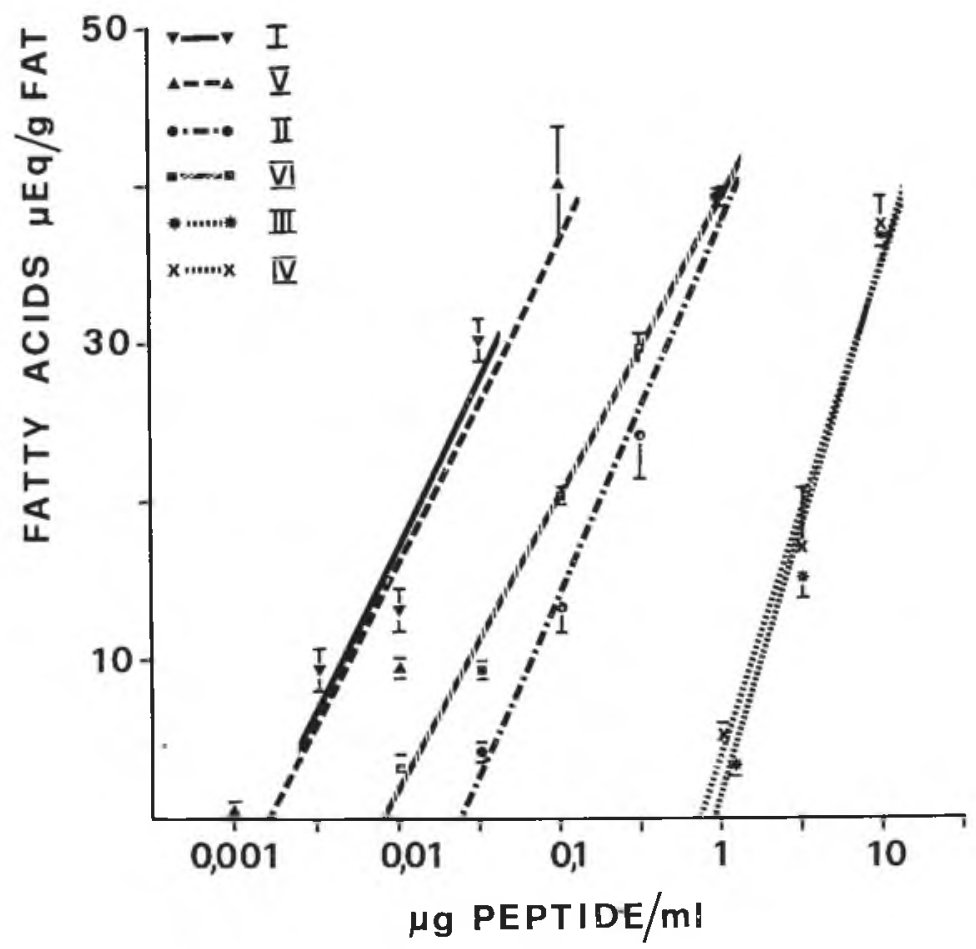

Fig. 2.

In vitro lipolysis: Dose-response regression lines of FFA released from rat epididymal fat pads incubated for $2 \mathrm{~h}$ at $37^{\circ} \mathrm{C}$. Each point constitutes the mean of 4 to 8 incubations \pm sEM. 
Table 3.

In vitro lipolysis: activities determined by glycerol release (epididymal fat pads of rats).

\begin{tabular}{|c|c|c|c|c|c|c|c|c|}
\hline \multirow{2}{*}{$\begin{array}{c}\text { Test } \\
\text { compound }\end{array}$} & \multicolumn{8}{|c|}{$\mu \mathrm{g}$ peptide fer $\mathrm{ml}$ incubation medium } \\
\hline & 0.001 & 0.01 & 0.03 & 0.1 & 0.3 & 1.0 & 3.0 & 10 \\
\hline I & $0.9 \pm 0.2^{*}$ & $8.2 \pm 0.6$ & $15.9 \pm 0.3$ & $20.7 \pm 0.6$ & - & - & - & - \\
\hline II & - & $0.2 \pm 0.2$ & $2.7 \pm 0.7$ & $9.1 \pm 0.8$ & $14.7 \pm 1.6$ & $21.2 \pm 0.7$ & - & - \\
\hline III & - & - & - & - & $2.3 \pm 0.5$ & $3.8 \pm 1.2$ & $10.0 \pm 3.5$ & $19.0 \pm 1.2$ \\
\hline IV & - & - & - & - & $0.5 \pm 0.2$ & $4.7 \pm 1.3$ & $9.8 \pm 4.0$ & $20.3 \pm 4.0$ \\
\hline v & $1.2 \pm 0.5$ & $7.9 \pm 0.6$ & - & $20.0 \pm 1.5$ & - & - & - & - \\
\hline VI & - & $4.6 \pm 1.2$ & $7.1 \pm 1.2$ & $15.5 \pm 0.5$ & $19.1 \pm 0.1$ & $20.4 \pm 1.3$ & - & - \\
\hline
\end{tabular}

$* \mu \mathrm{Mol}$ glycerol per $\mathrm{g}$ fat; each value is the mean of 6-9 incubations. 
than the former. The two peptides substituted with $\mathrm{Har}^{8}$ (II and VI) yield dose-response regression lines parallel to those of the respective standards; their relative potencies, as determined in 4-point assays, amounts to about 0.25 of that of the standards $(=1)$. The two analogues III and IV, substituted with $\mathrm{Orn}^{8}$ and $\mathrm{Lys}^{8}$ respectively, are markedly less active. In the 4 -point assays they differ from the standards in the slope of their dose-response regression lines, so that no valid comparison of their potencies can be made. At the semi maximal activity level (middle part of the regression lines), their potency in relation to that of the respective standards is about 0.04 .

\section{Lipolysis in vitro (Fig. 2, Table 3)}

The mobilization of unesterified fatty acids (FFA, Fig. 2) and the release of glycerol are in good overall agreement with the steroidogenic activity of the peptides. The two standards, I and V, show equal activity. The two $\mathrm{Har}^{8}$

\section{TETRACOSA-PEPTIDES}

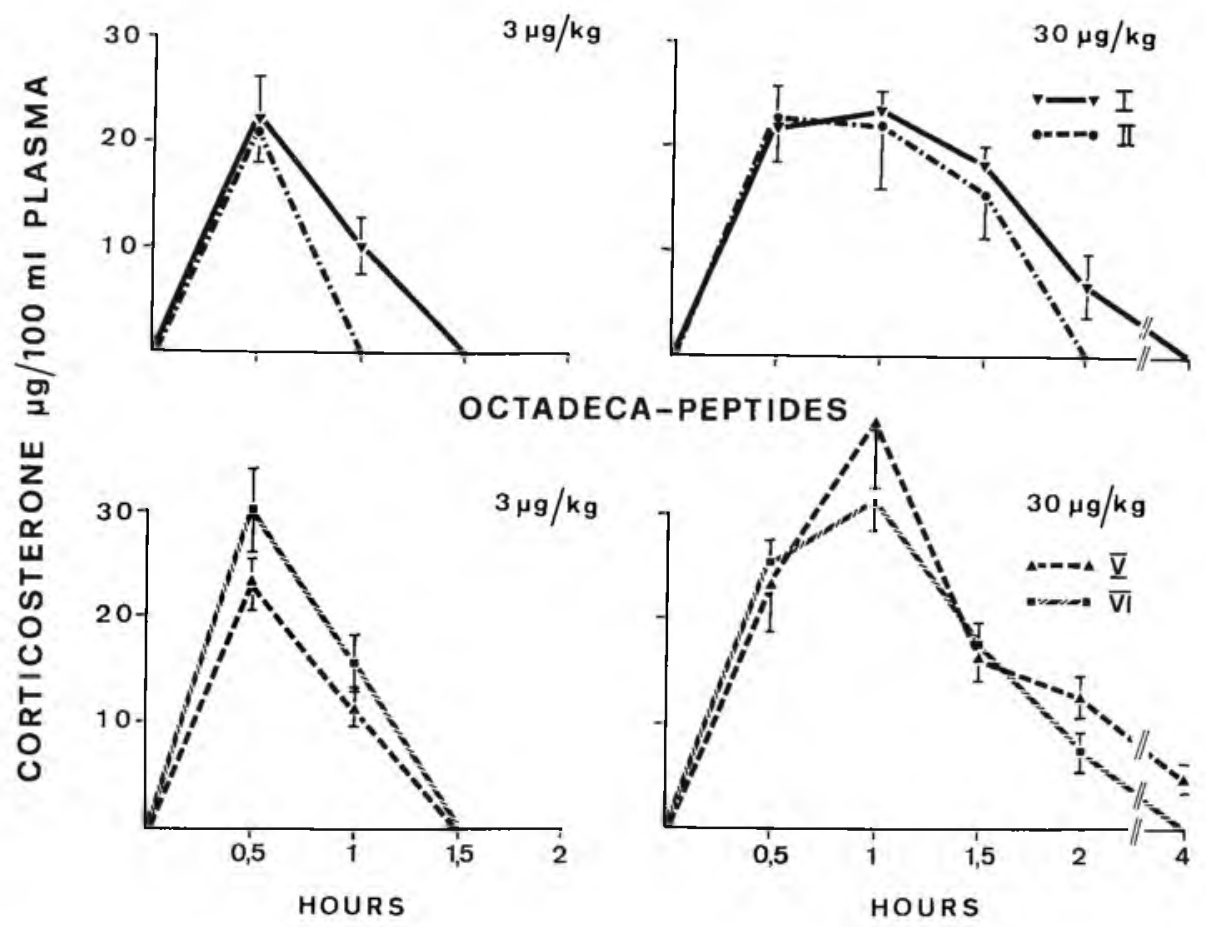

Fig. 3.

In vivo steroidogenesis: Time course of plasma corticosterone concentrations in $24 \mathrm{~h}$ hypophysectomized rats after a single intravenous injection of the peptides. Each point represents the mean of 6 to 12 animals \pm SEM. 
peptides, II and VI, also exhibit similar activity. Their dose-response regression lines are parallel to those of the standard compounds but a dose 10 times higher is necessary to obtain the same lipolytic effect. The two peptides with $\mathrm{Orn}^{8}$ or Lys ${ }^{8}$ (III and IV) yielded somewhat steeper dose-response curves than the other corticotrophin peptides. When compared at the level of medium effect (20 $\mu \mathrm{Mol} / \mathrm{g}$ fat) both peptides proved to be about 300 times less active than the standard compounds. The results obtained by measuring glycerol-release are identical to those found by determining FFA mobilization (Table 3).

Steroidogenesis in vivo (Fig. 3)

Steroidogenic activity in vivo was assessed on the basis of the time-response curves obtained after the intravenous administration of single doses of 3 and $30 \mu \mathrm{g} / \mathrm{kg}$ of each of the peptides.

At these dose levels, the maximum corticosterone concentrations produced by the 4 peptides tested (I, II, V and VI; III and IV were not assayed) do not

\section{TETRACOSA-PEPTIDES OCTADECA-PEPTIDES}
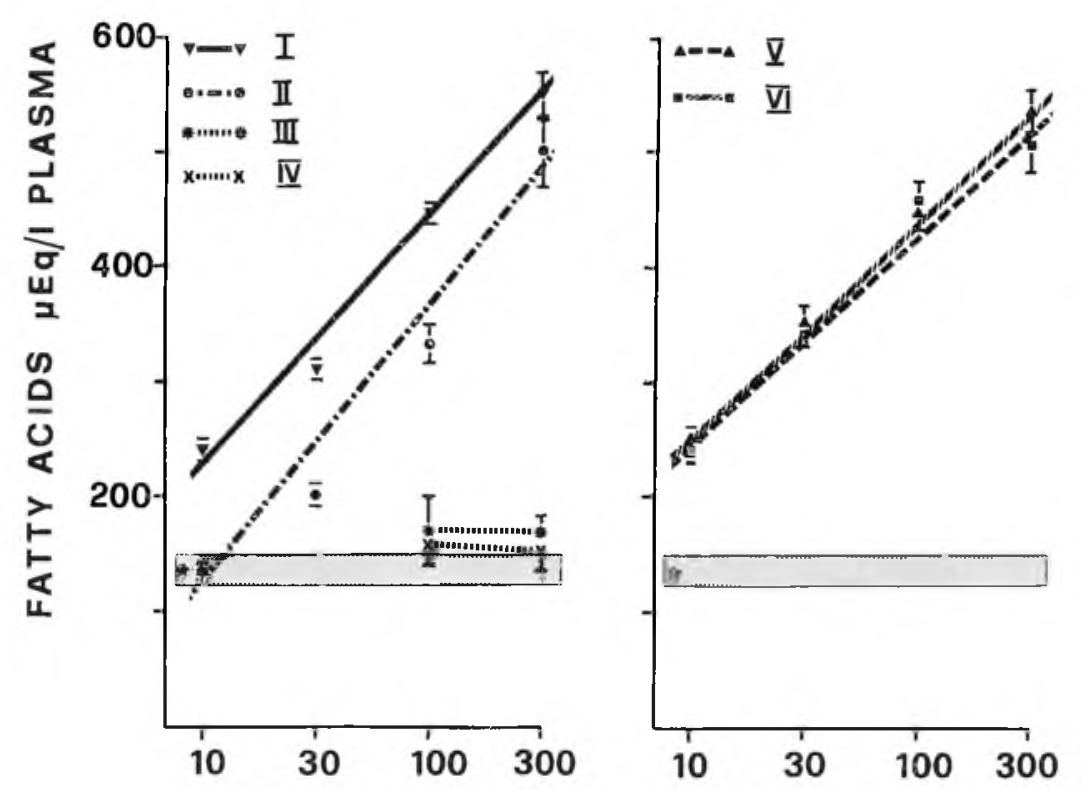

$\mu \mathrm{P}$ PEPTIDE/kg BODY WEIGHT

Fig. 4.

In vivo lipolysis: Dose-response regression lines of plasma FFA concentrations in intact rats $30 \mathrm{~min}$ after a single intravenous injection of the peptides. Each point represents the mean of $14-21$ animals \pm SEM. Basal values $(132 \pm 12)$ of 50 rats injected with saline only are shown as shaded area. 
differ significantly, but the duration of their steroidogenic effects varies. The two standard peptides have an almost identical duration of action, the 10 fold dose eliciting an almost doubly prolonged effect. The [Har ${ }^{8}$ ]tetracosapeptide (II) has a shorter duration of effect than the standards, I and V; a dose roughly three times greater than that of the standard peptide I would have to be given to achieve the same duration of effect. The $\left[\mathrm{Har}^{8}, \mathrm{Lys}^{17,18}\right]$ octadecapeptide (VI) does not differ significantly from the two standards.

\section{Lipolysis in vivo (Fig. 4)}

The slopes of the dose-response regression lines of the four active peptides are parallel. The standard compounds, I and V, and [Har ${ }^{8}$, Lys $\left.{ }^{17,18}\right]$ octadecapeptide (VI) display identical activity, whereas the [Har $\left.{ }^{8}\right]$ tetracosapeptide (II) is only half as potent. The two tetracosapeptides, III and IV, with Orn ${ }^{8}$ and $\mathrm{Lys}^{8}$ show no lipolytic activity up to the highest dose tested $(1 \mathrm{mg} / \mathrm{kg})$.

\section{I S G US S I O N}

The biological importance of arginine in position 8 of corticotrophin peptides has been investigated. Replacement of arginine by homo-arginine (Fig. 5) results in only a slight reduction in the steroidogenic and lipolytic activity of the peptides, while the substitution of ornithine or lysine drastically diminishes these effects.

The four analogues differ as regards not only the $\mathrm{pK}_{\mathrm{a}}$ of the basic group in position 8 (guanidino-group $\mathrm{pK}_{\mathrm{a}} 12.5$, amino group $\mathrm{pK}_{\mathrm{a}} 10.5$ ), but also the length of the aliphatic chain which carries the basic grouping. Our results clearly demonstrate the eminent importance of the guanidino group, while the length of the aliphatic chain is obviously of minor significance, the biological activity of the homo-arginine analogues being only slightly reduced.

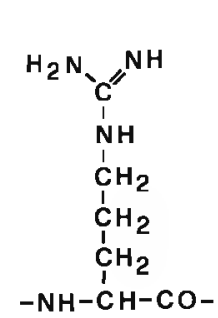

Arg

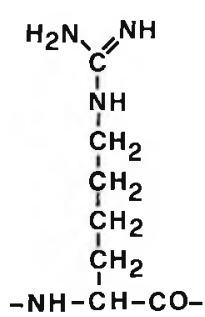

$\mathrm{Har}$

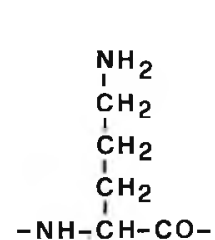

Orn

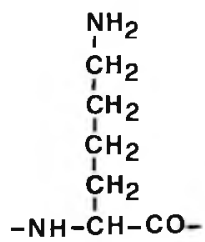

Lys

Fig. 5.

Chemical structures of the amino acids arginine (Arg), homoarginine (Har), ornithine (Orn) and lysine (Lys). 
These findings confirm and add precision to the results of earlier investigations (Tesser \& Schwyzer 1966; Tesser \& Rittel 1969) indicating the importance of arginine 8 . It has been shown that the arginyl residues in position 17 and 18 are not indispensable as regards biological activity; they can be replaced by ornithine (Tesser \& Schwyzer 1966) or by lysine (Desaulles et al. 1969) without substantially altering the effects of the peptides. The 11-24 region of corticotrophin is assumed to be essential to the binding of the peptide to its cellmembrane receptor, but is less important, if at all, for the stimulation of the receptor (Hofmann et al. 1970; Schwyzer et al. 1971; Finn et al. 1972). On the other hand, the 5-10 region is considered to represent the stimulating locus of corticotrophin. This diversity of function might explain the unequal importance of the arginyl residue in position 8 as compared with positions 17 and 18. To stimulate the receptor, a guanidino group is a necessity, while an amino group appears to be inadequate; in the binding region (17/18), however, either of the basic residues sufficies. It is tempting to believe that the receptor can discriminate between two groups whose base strengths differ by a factor of 100. Although this difference is most conspicuous, it is reasonable to assume that both residues are completely protonated in aqueous solution under physiological conditions prevailing in the serum or plasma.

It is therefore anticipated, that a protonated guanidino group in position 8 also occurs when the peptide is in intimate contact with the receptor site. The inadequacy of the ammonium group to stimulate the true receptor site migh1 be attributed to the small spatial extent of its positive charge in contradistinc-

Table 4.

Approximate potencies.

\begin{tabular}{c|c|c|c|c}
\hline \multirow{2}{*}{$\begin{array}{c}\text { Test } \\
\text { compound }\end{array}$} & \multicolumn{2}{|c|}{ Steroidogenesis } & \multicolumn{2}{c}{ Lipolysis } \\
\cline { 2 - 5 } & in vitro & in vivo & in vitro & in vivo \\
\hline \multirow{2}{*}{ I* } & 1 & 1 & 1 & 1 \\
II & 0.25 & 0.3 & 0.1 & 0.5 \\
III & 0.06 & - & 0.003 & $\phi^{* * * *}$ \\
IV & 0.04 & - & 0.003 & $\phi^{* * *}$ \\
V & 1 & 1 & 1 & 1 \\
VI & 0.25 & 1 & 0.1 & 1 \\
\hline
\end{tabular}

* Activity was arbitrarily set at 1 .

* Inactive up to a dose of $1 \mathrm{mg} / \mathrm{kg}$ iv. 
tion to the larger resonance-stabilized guanidinium group. The latter, moreover, affords the possibility of interaction with some bidentate structure in the receptor site by way of a hydrogen bond, additional to its electrostatic bond.

The steroidogenic and the lipolytic potencies of the peptides investigated in this study are indicated in Table 4 . It is evident that the relative activities of the tested corticotrophins are highly similar in the two in vitro test systems. It may therefore be speculated that the corticotrophin receptors of the adrenal and the fat cell are similar in structure.

\section{RE F E R E N C ES}

Chung D. \& Li C. H.: J. Amer. chem. Soc. 89 (1967) 4208.

Desaulles P. A., Riniker B. \& Rittel W. In: Margoulies M., Ed. Proteins and Polypeptide Hormones, Excerpta med. (Amst.) (1969) p. 489.

Desaulles P. A. \& Rittel W.: Investigations of Hypothalamic Pituitary-Adrenal Function, Memoires of the Soc. Endocr. No. 17 (1968) p. 125.

Dole V. P.: J. clin. Invest. 35 (1956) 150.

Duncombe W. G.: Biochem. J. 88 (1963) 7.

Finn F. M., Widnell C. C. \& Hofmann K.: J. biol. Chem. 247 (1972) 5695.

Finney D. J.: Statistical Method in Biological Assay, Griffin, London (1964).

Geiger R.: Angew. Chem. 83 (1971) 155.

Guillemin R., Clayton G. W., Lipscomb H. S. \& Smith J. D.: J. Lab. clin. Med. 53 (1959) 830.

Hofmann K., Wingerder W. \& Finn F. M.: Proc. nat. Acad. Sci. USA 67 (1970) 829.

IUPAC-IUB Commission of Biochemical Nomenclature: Biochem. J. 126 (1972) 173.

Jungas R. L. \& Ball E. G.: Biochemistry 2 (1963) 383.

Kappeler H. \& Schwyzer R.: Helv. chim. Acta 44 (1961) 1136.

Li C. H.: Science 129 (1959) 696.

Saffran M. \& Schally A. V.: Endocrinology 56 (1955) 523.

Schwyzer R., Schiller P., Seeling S. \& Sayers G.: FEBS Letters 19 (1971) 229.

Tesser G. I. \& Rittel W.: Rec. Trav. chim. Pays-Bas 88 (1969) 553.

Tesser G. I. \& Schwyzer R.: Helv. chim. Acta 49 (1966) 1013.

Wieland O.: Biochem. Z. 329 (1957) 313.

Received on January 29th, 1973. 
Tetrabedron Letters No. 11, pp 817 - 820, 1973. Pergamon Press. Printed in Great Britain.

\section{A NOVEL PHOTOCYCLIZATION, STARTING FROM 1,4-DIARYLBUTENYNES}

\section{A.H.A. Tinnemans and W.H. Laarhoven}

\section{Department of Organic Chemistry, Catholic University, Toernooiveld, Nijmegen, The Netherlands}

(Received in OK 25 January 1973; accepted for publication I February 1973)

Cis-trans isomerization is the only known photochemical reaction of arylbutenynes ${ }^{1}$ until now. We found, however, that irradiation under nitrogen of a dry and deaerated solution ( $5.10^{-4}$ molar) of 1 - ( $x$-naphthyl)-4-phenylbut-1-en$3-\mathrm{yn}^{2}$ (I) in benzene with a $360 \mathrm{~nm}$ fluorescence lamp (Sylvania blacklite F8T5) during four hours converted the solute into 1-phenylphenanthrene (IIa), 45\%.

Although no oxidation step is involved the cyclization is slightly faster in the presence of air; in a solution saturatcd with oxygen or supplied with a small amount of iodine $\left(3.10^{-5}\right.$ molar) the rate is about twice as fast as in a dearated and iodine-free solution.

The main irradiation product in a deaerated solution of I containing an equinolar arount of iodine is an iodo derivative, 1-phenyl-2-iodophenanthrene (IIa). On prolonged irradiation of this solution iodine is replaced by a phenyl group ${ }^{3}$, giving rise to an increasing amount of 1,2-diphenylphenanthrene (IIc, m.p. $151^{\circ}$ ).<smiles>C#CC=Cc1cccc2ccccc12</smiles>

I
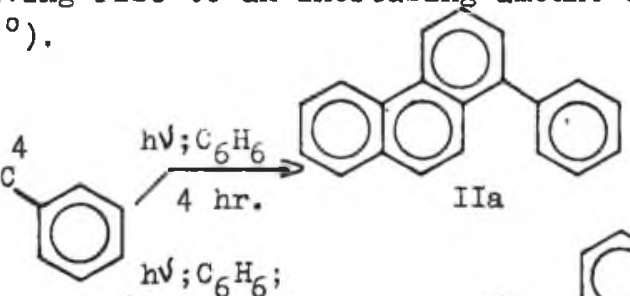

$4 \mathrm{hr}$.

II a

$\mathrm{IIa}+$ $15 \%$<smiles>[3H]c1ccc2c(ccc3ccccc32)c1-c1ccccc1</smiles>

IIb $(50 \%)$

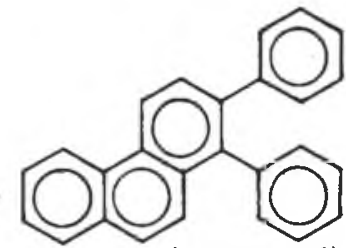

IIc (about 5\%)

The cyclization is a light-induced reaction. Refluxing a benzene solution of I in the dark or heating of pure I in an evacuated tube at $300^{\circ}$ during four hours did not yield any cyclization product.

Irradiation under nitrogen of an iodine-free solution of I (5.10-4 molar) in hexane in the presence of triplet-sensitizers like 2-methylanthraquinone, benzophenone, benzil or acetophenone $\left(0-1.2 \cdot 10^{-2}\right.$ molar) did not lead to higher yields of IIa. Also the presence of the triplet-quencher azulene did not influence the result of the photoreaction. 
The radical scavenger di-tert.butylnitroxide $\left(10^{-3}-4 \cdot 10^{-4}\right.$ molar $)$ had no influence upon the cyclization of I into IIa. However, on irradiation a solution of I containing iodine as well as this radical scavenger only ITa and not $I I b$ and IIc was formed.

From these results it may be concluded that IIa arises from a sirglet excited state of $I$. It is known that acetylenes in the first excited state have non-linear trans configurations ${ }^{5}$, which should be very favourable for the ring-closure observed. The formation of the new $\mathrm{C}-\mathrm{C}$ bond and the 1,5-hydrogen shift may be a concerted. I In the presence of iodine cyclization product IIb is apparently formed via a radical intermediate, possibly formed by the addition of an iodine atom to the triple bond of $I$.

The new photocyclization raction has been investigated on several other diarylbutenynes (Table).

\section{Table}

Irradiation products from diarylbutenynes ${ }^{2}$, $\mathrm{Ar}^{1}-\mathrm{CH}=\mathrm{CH}-\mathrm{C} \equiv \mathrm{C}-\mathrm{Ar}^{2}$

\begin{tabular}{|c|c|c|c|c|c|c|c|}
\hline \multirow[b]{2}{*}{$A r^{1}$} & \multirow[b]{2}{*}{$A r^{2}$} & \multicolumn{3}{|c|}{ without iodine } & \multicolumn{3}{|c|}{ with iodine } \\
\hline & & $\begin{array}{l}\text { pro- } \\
\text { duct }\end{array}$ & $\underset{\%}{\text { yield }}$ & $\mathrm{m} \cdot{ }^{n} \cdot{ }^{\circ} \mathrm{C}$ & $\begin{array}{l}\text { pro- } \\
\text { duct }\end{array}$ & yield & $\mathrm{m} \cdot \mathrm{p} \cdot{ }^{\circ} \mathrm{C}$ \\
\hline $1 \alpha-n a p h t y l$ & phenyl & IIa & 45 & $74-76$ & IIb & 50 & $166-168$ \\
\hline 2 phenyl & phenyl & - & & & - & & \\
\hline 3 p. methoxyphenyl & phenyl & - & & & - & & \\
\hline 4 3,5-dimethylphenyl & phenyl & IIIa & 44 & liquid & \#) & & \\
\hline $5 \beta$-naphthyl & phenyl & IVa & 55 & $82-84$ & $\mathrm{IVb}$ & 44 & $160-162$ \\
\hline $6 \alpha-(4-m e t h y l$ naphthyl $)$ & phenyl & IId & 54 & $89-92$ & IIe & 19 & $93-95$ \\
\hline $7 \beta-(8-$ phenylnaphthyl $)$ & phenyl & IVc & 65 & $169-171$ & IVd & 16 & $135-140$ \\
\hline 8 3-phenanthryl & phenyl & $\mathrm{Va}$ & 50 & $109-113$ & $\mathrm{Vb}$ & 32 & $131-133$ \\
\hline 9 2-benzo [e]phenanthryl & phenyl & - H* & & & - & & \\
\hline $109-(1-$ phenylphenanthryl $)$ & phenyl & $\mathrm{VIa}$ & 60 & $150-152$ & $\mathrm{VIb}$ & 44 & $254-260$ \\
\hline 11 phenyl & $\alpha$-naphthyl & - & & & - & & \\
\hline $12 \alpha$-naphthy 1 & $\alpha_{-n a p h t h y l}$ & VIIa & 22 & $116-118$ & ¥) & & \\
\hline $13 \beta$-naphthy 1 & $\alpha$-naphthyl & VIIIa & 38 & $150-152$ & VIIIb & 38 & $137-140$ \\
\hline
\end{tabular}

* Irradiation had to be carried out with a high pressure mercury lamp in hexane; under these circumstances carbon-iodine bonds are broken.

*3) only a mixture of dimers had been formed. 


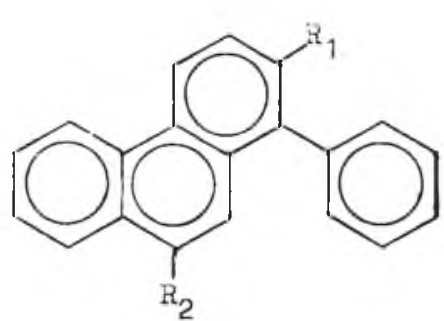

$$
\begin{aligned}
\text { IIa: } R_{1}=R_{2}=H \\
\text { b: } R_{1}=I, R_{2}=H \\
c: R_{1}=C_{6} H_{5}, R_{2}=H \\
\text { d: } R_{1}=H, R_{2}=C_{3} \\
\text { e: } R_{1}=I, R_{2}=\mathrm{CH}_{3}
\end{aligned}
$$

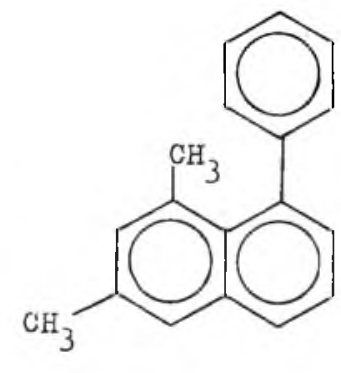

IIIa

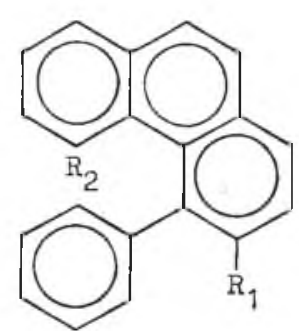

IVa: $R_{1}=R_{2}=H$ b: $R_{1}=I, R_{2}=H$

c: $\mathrm{R}_{1}=\mathrm{H}, \mathrm{R}_{2}=\mathrm{C}_{6} \mathrm{H}_{5}$ d: $R_{1}=I, R_{2}=C_{6} H_{5}$
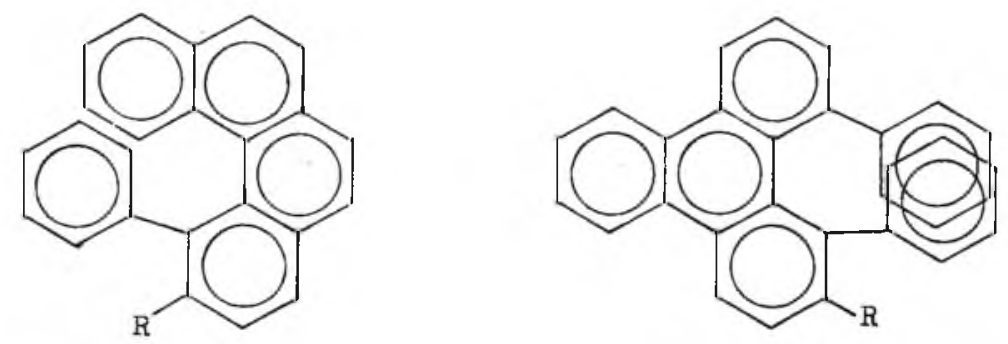

$\mathrm{Va}: \mathrm{R}=\mathrm{H}$

$\mathrm{b}: \mathrm{R}=\mathrm{I}$

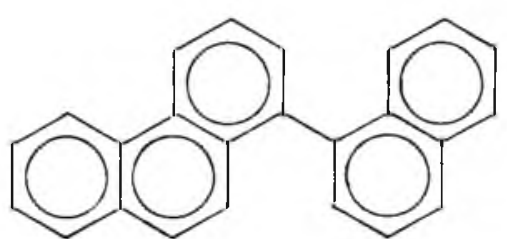

VIa: $\mathrm{R}=\mathrm{H}$

$\mathrm{b}: \mathrm{R}=\mathrm{I}$

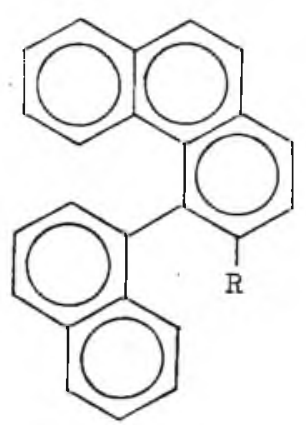

VIIa

VIIIa: $\mathrm{R}=\mathrm{H}$

$\mathrm{b}: \mathrm{R}=\mathrm{I}$ 
The negative results in the experiments 2,3 and 11 compared with the cyclization in 4 suggest that some factor related to the electron-distribution in the relevant ring is of decisive importance for the cyclization. The failure of cyclization in experiment 9 may be due to the strong tendency of the starting compound to dimerization, even in dilute solutions. In all other cases only one type of cyclization product was obtained; bond formation occurs always between an acetylenic carbon $\left(C_{4}\right.$ in $\left.I\right)$ and the aromatic ring at $C_{1}$. In this respect the reaction is clearly different from photocyclizations in diarylbutadienes 6 , which lead to two products if different arylresidues are present in the starting compound ${ }^{7}$. The experiments 7,8 and 10 reveal that even highly crowded polycyclic aromatics can be obtained quite specifically and in good yields from properly chosen diarylbutenynes.

Full experimental details concerning the syntheses and spectroscopie data and properties of the products will be given elsewhere.

\section{Acknowledgement:}

The investigation was carried out under the auspices of the Netherlands Foundation for Chemical Research (S.O.N.) with financial support from the Netherlands Organization for Advancement of Pure Research (Z.W.O.).

\section{References and notes}

1. G. Quinkert, H. Hintzmann, P. Micha'elis, P. Jürges, H. Appelt and U. Krijger, Ann. 748, 38 (1971).

2. The butenynes were synthesized by Wittig reactions from arylpropargylaldehydes and triphenylphosphonium salts of apropriate bromomethyl aromatics in methanol or DMF as solvent and with sodium methoxide as base.

3. R.K. Sharma and N. Kharasch, Angew. Chem. 80, 69 (1968).

4. A.K. Hoffmann, A. îi. Feldman, E. Gelblum and V.G. Hodgson, J. Am. Chem. Soc. 36, 639 (1964).

5. J. Dale in H.G. Viehe, Chemistry of Acetylenes, Harcel Dekker, New York, 1969, p. 52.

6. R.J. Hayward, A.C. Hopkinson and C.C. Leznoff, Ietrahedron 28, 439 (1972).

7. Although Leznoff mentioned high specificity in photocyclizations of 1,4-diarylbutadienes we found in general more than one product. This discrepancy may be due to the very low yields (about 10\%) in Leznoff's experiments. 


\title{
SIMPLE ASSAY OF PLASMA TESTOSTERONE USING A COVALENT PROTEIN-SEPHAROSE COMPLEX
}

\author{
Hans-Ulrich FISCH, Vladimir PLISKKA, Godefridus I. TESSER \\ and Robert SCHWYZER \\ Dept. of Molecular Biology and Biophysics, \\ Swiss Federal Institute of Technology (ETH), CH-8049 Zürich, Switzerland \\ and \\ Milo ZACHMANN \\ Dept. of Pediatrics, University of Zürich, 8032-Zürich, Switzerland
}

Received 17 November 1972

\section{Introduction}

In previous communications, we [1] described the use of Sepharose-linked binding proteins for a convenient and precise assay of cyclo-3', $5^{\prime}$-adenosine monophosphate (cAMP) according to the principle of competitive protein binding (CPB) between unlabelled and labelled cAMP. The method had the advantage of allowing a simple and rapid separation of "bound" from "free" radioactive $c$ AMP by mere filtration of the "immobilized" protein linked to the Sepharose. It avoided all the difficulties arising with soluble cAMP binding proteins that had been in use hitherto (for references see [1]).

It occurred to us that similar improvements could possibly be achieved for the CPB assays of plasma testosterone. In a collaborative effort, we succeeded in devising an equally convenient and precise testosterone assay using Sepharose-linked testosterone binding proteins from human late pregnancy serum.

\section{Materials and methods}

Water was deionized and twice distilled before use. For measuring aqueous solutions, we used Oxford, for solutions in organic solvents, glass pipettes. Buffer I: $0.1 \mathrm{~N} \mathrm{NaHCO}_{3} / 0.1 \mathrm{~N} \mathrm{NaCl}$; buffer II: $0.05 \mathrm{M}$ Tris$\mathrm{HCl}, \mathrm{pH} 7.4$.

\subsection{Sepharose-linked testosterone binding proteins}

$3 \mathrm{~g}$ of Sepharose activated with cyanogen bromide (purchased from Pharmacia or prepared according to [1]) were suspended in $10 \mathrm{ml}$ of buffer I and kept for $20 \mathrm{~min}$ at room temp. The gel was transferred to a porous glass filtration funnel and washed for not more than $15 \mathrm{~min}$ with approx. $200 \mathrm{ml}$ of $0.001 \mathrm{~N}$ $\mathrm{HCl}$ to remove soluble impurities. The material on the filter was then washed with approx. $200 \mathrm{ml}$ of buffer I, sucked almost dry, and transferred to a solution of $2 \mathrm{ml}$ of human late pregnancy serum (third trimester) in $5 \mathrm{ml}$ of buffer I contained in a $100 \mathrm{ml}$ round bottomed flask. The mixture was gently stirred by slow rotation of the flask at $4^{\circ}$ for $15 \mathrm{hr}$. The proteinmodified Sepharose was collected on a porous glass filter and washed with $250-500 \mathrm{ml}$ of buffer I, followed by $250-500 \mathrm{ml}$ of buffer II. The gel was then suspended in $200 \mathrm{ml}$ of buffer II and stored until used at approx. $1-4^{\circ}$ in a beaker sealed with "Parafilm".

\subsection{Assay of "testosterone-like substances" in blood plasma}

2.2.1. Preparation of plasma extracts and blanks

The heparinized blood was immediately centrifuged and the plasma stored at $-20^{\circ}$ in plastic vials. $1.0 \mathrm{ml}$ of the plasma (or a smaller amount diluted to $1.0 \mathrm{ml}$ with water) was placed, together with $5.0 \mathrm{ml}$ of spectroscopic grade dichloromethane, into a glass- 
stoppered vial and agitated for $1 \mathrm{~min}$. The aqueous phase was pipetted off and replaced with $0.5 \mathrm{ml} 1 \mathrm{~N}$ $\mathrm{Na}_{2} \mathrm{CO}_{3}$ solution. After agitation ( $30 \mathrm{sec}$ ) and centrifugation, the aqueous phase was removed, and the organic phase washed neutral with two to three successive $0.75 \mathrm{ml}$ volumes of water (test with $\mathrm{pH}$ paper). Four $0.50 \mathrm{ml}$ aliquots of the organic phase were pipetted into four Eppendorf vials and kept in a vacuum desiccator for at least $1 \mathrm{hr}$ at approx. 10 Torr. For the estimation of blank values, $1.0 \mathrm{ml}$ of water was treated in exactly the same manner as the plasma samples.

\subsubsection{Calibration}

For every assay (double estimations of the unknowns) a calibration curve was constructed, using $50 \mu \mathrm{l}$ each of ethanolic solutions containing in this volume $5.0,1.25,0.32,0.008$, and zero ng of testosterone in Eppendorf vials. The solvent was removed as in sect. 2.2.1.

\subsubsection{Binding assay}

$100 \mu \mathrm{l}$ of $\left[1,2-{ }^{3} \mathrm{H}\right]$ testosterone (Amersham) in water $(=10 \mathrm{nCi})$ were added to each of the desiccated vials (mechanical shaking for $30 \mathrm{sec}$ dissolved the dried extract or blank). The protein-modified Sepharose in the storage beaker was evenly suspended by slow magnetic stirring, and $200 \mu \mathrm{l}$ each of the suspension pipetted into the vials. After mechanical agitation for $5 \mathrm{sec}$, equilibration was achieved by standing at room temp. for unspecified times between 20 and $120 \mathrm{~min}$. The contents of the vials were then pipetted onto $35 \mu \mathrm{m}$ polyester nets (Müllereigaze Estal mono PE 35, No. 19176, Schweizerische Seidegazefabrik AG., Thal, Switzerland) contained in suction filter funnels. The vials were rinsed with $1 \mathrm{ml}$ each of buffer II, and the materials on the filters washed once or twice with approx. $1 \mathrm{ml}$ of the same buffer (volumes aren't critical). The nets were transferred into the counting vials and covered with $5 \mathrm{ml}$ of the scintillant solution (Insta-Gel, Packard). After agitation, the radioactivity was determined by scintillation counting (Packard Tri-Carb instrument). It was usually expressed in percentage of a $100 \%$ value $(=100 \mu \mathrm{l}$ of the above $\left[1,2-{ }^{3} \mathrm{H}\right]$ testosterone solution added to the scintillant).

\section{Results}

\subsection{Properties of the "Sepharose-linked testosterone binding proteins"}

The mean association constant for $\left[1,2-{ }^{3} \mathrm{H}\right]$ testosterone in $33 \mathrm{mM}$ Tris- $\mathrm{HCl}$ buffer, $\mathrm{pH} \mathrm{7.4,} \mathrm{at} 20^{\circ}$, and the Hill coefficients, $n$, were determined according to the method described in [1]: $K_{\text {ass }}=9.87 \times 10^{8} 1 / \mathrm{mole}$ $\left(K_{\text {diss }}=1.01 \times 10^{-9} \mathrm{~mole} / 1\right) ; n=1$. The non-specific adsorption of $\left[1,2-{ }^{3} \mathrm{H}\right]$ testosterone to Sepharose and to the polyester net is less than $1 \%$ of the total tracer concentration added.

\subsection{Water blank}

The water blank is considerably lower with the present method $\left(\overline{\mathrm{x}}=6.8 \mathrm{ng} / 100 \mathrm{ml}, \mathrm{S}_{\overline{\mathrm{X}}}=2.2, n=5\right)$ than with Florisil $2\left(\overline{\mathrm{x}}=64.6 \mathrm{ng} / 100 \mathrm{ml}, \mathrm{S}_{\overline{\mathrm{x}}}=4.6\right.$, $n=13$ ). In both cases, the extraction was carried out with dichloromethane, the solvent giving the lowest "reagent blank" [3].

\subsection{Plasma testosterone values}

Results obtained with the present method from samples of normal subjects and patients with various

Table 1

Plasma testosterone values in normal pubertal and adult males.

\begin{tabular}{lll}
\hline Subject No. & $\begin{array}{l}\text { Age } \\
(\mathrm{yr})\end{array}$ & $\begin{array}{l}\text { Plasma } \\
\text { testosterone } \\
\text { (ng/100 ml) }\end{array}$ \\
\hline 1 & 15 & 644 \\
2 & 16 & 680 \\
3 & 16 & 685 \\
4 & 17 & 410 \\
& & $1000^{*}$ \\
& & $1025^{*}$ \\
5 & $1300^{*}$ \\
6 & 17 & 465 \\
7 & 17 & 470 \\
8 & 19 & 530 \\
9 & 20 & 800 \\
10 & 21 & 455 \\
Mean value $\pm \mathrm{s}$ & 54 & 980 \\
\hline
\end{tabular}

* = 2, 4 and 6 days after administration of human chorionic gonadoptropin (5000 U per square meter of body surface area). 
Table 2

Plasma testosterone values in patients with various disorders.

Subject No.
High values

1

2

3

19

8

30

F
M

M

M

6

(

Age

(yr)

Sex

Diagnosis
Plasma testosterone (ng/100 ml)
750

puberty, untreated

1140

Idiopathic precious

puberty untreated

Under treatment with

410

cyproterone acetate

Testicular teratoma, untreated

After surgery 235

Idiopathic hirsutism

210

Idiopathic hirsutism

380

Idiopathic hirsutism

450

Congenital adrenal hyperplasia (21-hydroxylase deficiency), untreated

Virilizing adenoma of the left adrenal:

Left adrenal venous plasma

Right adrenal venous plasma

6500

1600

\section{Low values}

\section{9}

0.6

M

M

10

4

6

M

M

12

52

16

13

14

15

16

17

17

18

19

17

35

40

Tall stature within normal limits

Hereditary defect of testosterone biosynthesis $(17,20$-desmolase deficiency)

$\begin{array}{ll}\text { Congenital anorchia } & 10\end{array}$

Castrate, untreated 25

Delayed puberty 105

Delayed puberty 210

Delayed puberty 260

Delayed puberty 345

Delayed puberty $\quad 130$

Delayed puberty $\quad 171$

Klinefelter's syndrome $\quad 165$

Hypogonadism 120

$\begin{array}{lr}\text { Hypogonadism } & 175\end{array}$ 
endocrine disorders are displayed in tables 1 and 2 . They agree well with those reported by others using different techniques $[4,5]$. The mean value obtained in normal pubertal and adult males was $612 \pm 172$ $\mathrm{ng} / 100 \mathrm{ml}(n=10)$, while a compiled average from the literature [5] is $670 \pm 230 \mathrm{ng} / 100 \mathrm{ml}$. The highest figure was obtained for adrenal venous blood from a patient with virilizing adrenal adenoma $(6500 \mathrm{ng} / 100$ $\mathrm{ml}$, patient No. 8, table 2). High values were also found in untreated patients suffering from congential adrenal hyperplasia due to a 21-hydroxylase deficiency and from idiopathic precocious puberty. In the latter condition, there was, in one case studied, a definite reduction of the level during treatment with cyproterone acetate. Low values were obtained in an adult, unsubstituted castrate male, in a boy with congenital anorchia, and in one child with a congenital defect of testosterone biosynthesis (17,20-desmolase deficiency, proven by incubation of testicular tissue with testosterone precursors [6]). Moderately low levels were found in cases with benign delayed puberty, Klinefelter's syndrome, and hypogonadism, as one would expect.

\section{Discussion}

The competitive protein binding technique for the assay of hormones in biological fluids was introduced by Ekins (1960) for thyroxin [7]. Subsequently, Murphy $[8,9]$ adapted the principle for the estimation of steroids. A large number of methods for the determination of various steroids using $\mathrm{CPB}$ has since been published (for references and discussion see [10]. These techniques have the advantage of relative simplicity and high sensitivity. Their specificity, however, depends on the prepurification steps applied rather than on the CPB itself.

Among other difficulties, one of the major problems of CPB techniques is the separation of the free from the protein bound steroid fraction. For this purpose, various methods have been used, including gel filtration (Sephadex G25 [11], dextrane coated charcoal [12], ammonium sulfate for protein precipitation [13], and Florisil, p.e. [2, 14, 15]). We have, in the Dept. of Pediatrics, been previously using a modification of the relatively simple and non-specific method of Anderson [2] for the determination of "testosterone-like" substances in plasma, where no prepurifica- tion is carried out and the separation of the free from the bound fraction is done with Florisil. Our modifications consisted of extraction with methylene chloride instead of ether (lower non-specific "reagent" blank, cf. [3]), of a different CPB step, cf. [16], and of minor changes of shaking.

Although for clinical use, the results obtained with this previous method agreed well with those of urinary steroid determinations in the same subjects by highly specific gas chromatographic techniques (Zachmann [17]), the separation step with Florisil was a constant source of difficulties and did impair the reproducibility of the calibration curves due to its sensitivity to even minimal changes of shaking time and other methodological factors. In addition, in our experience and in that of others $[9,15]$, too high testosterone values were obtained with Florisil in plasma samples from prepubertal children and females, and the water blanks were relatively high.

Similar difficulties had been encountered in the CPB assays of $c$ AMP and had been overcome by the use of relatively very stable, Sepharose-linked $c$ AMP binding proteins [1]. The results presented in this paper show that analogous improvements can be achieved for steroid assays with the help, of immobilized binding proteins. The advantages consist in: i) rapid and facile separation of bound and free steroid fractions by simple filtration, ii) the constant equilibrium between $20 \mathrm{~min}$ and at least $3 \mathrm{hr}$, resulting in improved reproducibility of the standard curves and relative insensitivity to changes in handling times, iii) reduction of the water blank, iv) no observable desorption of testosterone during filtration and washing procedures, v) the negligible nonspecific adsorption of testosterone to Sepharose and polyester net, and vi) the stability of the Sepharose-linked protein.

\section{Acknowledgements}

The authors are grateful to Mrs. B. Manella (Dept. of Pediatrics, University of Zürich) for skillful technical assistance. Supported by the Swiss National Foundation for Scientific Research, grants No. 3.374.70 SR and 3.679.71.

Human late pregnancy serum was kindly supplied by PD Dr. P. Keller, Dept. of Obstetrics and Gynecology, University of Zürich. 


\section{References}

[1] H.-U. Fisch, V. Plǐska and R. Schwyzer, Experientia (Basel) 28 (1972) 630; European J. Biochem. 30 (1972) 1.

[2] D.C. Anderson, Clin. Chim. Acta 29 (1970) 513.

[3] A. Vermeulen and L. Verdonck, in: Steroid Assays by Competitive Protein Binding, ed. E. Diczflusy (Acta Endocr., Kbh., 1970), Suppl. 147 p. 239.

[4] A.E. Kellie and E.R. Smith, Biochem. J. 66 (1967) 490; J. Sjövall and R. Vihko, 2nd Intern. Congr. Hormonal Steroids, Excerpta Med. Found. Intern. Congr. Series No. 132 (1967) 210;

H.M. Gandy and R.E. Peterson, J. Clin. Endocr. 28 (1968) 949;

M.A. Rivarola, C. Bergada and M. Cullen, J. Clin. Endocr. 31 (1970) 526.

[5] E.E. Baulieu and P. Robel, in: The Androgens of the Testis, ed. E. Eik-Nes (Marcel Dekker Inc., New York, 1970) p. 49.

[6] M. Zachmann, W. Hamilton, J.A. Völlmin and A. Prader, Acta Endocr. Kbh., Suppl. 155 (1971) 65;

M. Zachmann, J.A. Völlmin, W. Hamilton and A. Prader, Clin. Endocrinol. 1 (1972) in press.

[7] R.P. Ekins, Clin. Chim. Acta 5 (1960) 453.

[8] B.E.P. Murphy, W. Engelberg and C.J. Pattee, J. Clin. Endocr. 23 (1963) 293;

B.E.P. Murphy, Nature 201 (1964) 679;
B.E.P. Murphy and C.J. Pattee, J. Clin. Endocr. 24 (1964) 919.

[9] B.E. Murphy, J. Clin. Endocr. 27 (1967) 973;

B.E.P. Murphy, in: Progress in Endocrinology, ed.

C. Gual, Excerpta Med. Found. Intern. Congr. Series No. 184 (1969) 458.

[10] E. Diczfalusy, Acta Endocr. Kbh., Suppl. 147 (1970).

[11] A. Vermeulen and L. Verdonck, Steroids 11 (1968) 60s T. Kato and R. Horton, Steroids 12 (1968) 631; A. Uettwiller, Zschr. Klin. Chem. Klin. Biochem. 8 (1970) 225 .

[12] R. Horton, T. Kato and R. Sherins, Steroids 10 (1967) 245;

R.L. Rosenfleld, W.R; Eberlein and A.M. Bongiovanni, J. Clin, Endocr. 29 (1969) 854.

[13] D. Mayes and C.A. Nugent, J. Clin. Endocr. 28 (1968) 1169;

R. Maeda, M. Okamoto, L.C. Wegienka and P.H. Forsha Steroids 13 (1969) 83.

[14] G.R. Fritz and E. Knobil. Federation Proc. 26 (1967) 757 ;

J. Frick and F.A. Kincl, Steroids 13 (1969) 495.

[15] M.C. Hallberg, E.M. Zorn and R.G. Wieland, Steroids 12 (1968) 241.

[16] J.A. Demetriou and F.G. Austin, Clin. Chem. 16 (1970) 111.

[17] M. Zachmann, Acta Endocr. Kbh., Suppl. 164 (1972) 70 . 